\title{
The challenges facing legumes in a dryland environment - a consultant's view
}

\author{
C. D. BROWN ${ }^{1}$, R. B. GREEN ${ }^{2}$ \\ ${ }^{1}$ Wrightson Solution Ltd, Private Bag 1966, Dunedin \\ ${ }^{2}$ Agricom (New Zealand) Ltd, P O Box 539, Ashburton
}

\begin{abstract}
The dryland regions of New Zealand suffer from summer moisture deficits in the majority of years. These dryland regions have been developed along the same basis as other farming regions, with increasing fertiliser usage leading to more subdivision and higher stocking rates. Given the exposure to droughts, the production per head of these regions has been extremely variable. Historically, dryland farming systems have been based around breeding ewe systems with all lambs finished if the season allowed. Since the removal of all Government support during adverse events, in the early 1990 s, farm systems have become considerably more diverse. Irrigation areas have doubled between 1985 and 1999 to approximately 500000 hectares. Both sub clover and lucerne have been used extensively in dryland areas, but the main legume is still white clover. Farmers recognise the significant limitations in the ability of white clovers to cope with summer droughts, but have not been able to efficiently utilise other legumes, which require unique management to perform. There are a number of reasons for this. Looking forward, the five key roles that legumes have in dryland farming systems are, to persist within a general purpose pasture, to produce nitrogen, to improve summer feed quality, to improve year round quality feed through specialist crops and pastures and to provide specialist composite feeds (i.e. condensed tannins). With the increased diversity in farming systems, growers require a more diverse range of legumes from perennial species to annuals that will fit a short-term high feed quality niche.
\end{abstract}

\section{Introduction}

The dryland farming regions of New Zealand make up a significant area of the east coast stretching from Hawke's Bay in the North Island down to East Otago in the South Island. There are also other pockets of dryland regions in inland areas of Central Otago and South Canterbury. Dryland farming regions are generally defined within the farming community as those environments where summer evapotranspiration exceeds summer rainfall in the majority of years. A total of 2872295 hectares of land received $800 \mathrm{~mm}$ of annual rainfall or less between the period $1950-1980$ (Table 1). This is $10.7 \%$ of the total New Zealand land area.

Within the dryland areas there are both extensive, semi-intensive and intensively farmed areas. The extensively farmed environments are generally in the South Island hill and high country and are based around adult beef cattle and merino-based sheep breeds. This paper focuses more on the intensive and semi intensive areas with less than 15 degrees slope.

\section{History}

These dryland areas were among the earliest to be settled and farmed in New Zealand, because their flat rangeland nature was well suited to extensive pastoral systems. They were also well suited to cereal cropping, which naturally led to increased intensification and development through sowing of "English grasses". The soldier resettlements following both World Wars also added further development

Table 1 Total hectares of New Zealand with $800 \mathrm{~mm}$ annual rainfall and less (1950-1980).

\begin{tabular}{lccc}
\hline & Total area (ha) & $<800 \mathrm{~mm}$ annual rainfall all land classes & \% of Total \\
\hline South Island & 15310227 & 2855989 & 18.65 \\
North Island & 11443537 & 16306 & 0.14 \\
\hline Total & 26753766 & 2872295 & 10.7 \\
\hline
\end{tabular}

(Source: Agribase data 2003, MAF Policy) 
impetus. With tractors replacing horses in the 1950s, typical farming systems involved 5-10 year pasture renewal rotations through brassicas, cereal straw crops, and ryegrasses. The inability of white clover to cope with summer drought was already well recognised, and sub-clover was often the most important legume component. Ryegrass varieties were limited to 'Ruanui' and 'Paeroa.' The release of 'Tama' in the 1970s was a major technology advance at that time. Soil $\mathrm{pH}$ levels were typically only 5.4, and phosphate levels were 6 - little wonder clover struggled to survive. The 1970s saw increased use of fertiliser, lime, and subdivision, and considerable use of lucerne as an option to "drought-proof" farms. Subsidy and incentive schemes designed to boost pastoral production (e.g. $\$ 1$ per sheep in the budget of 1975, and land development encouragement loans), combined with central government assistance in times of drought, meant farms were basically overstocked and per head productivity remained static for 30 years (Brown 1996)

By the mid 1980s the use of lucerne had all but disappeared, due to the main variety's ('Wairau') susceptibility to pests and disease. The introduction of crossbred sheep breeds over this period, resulting from a crash in wool prices, led to a significant increase in meat output. Soil fertility levels continued to improve slowly, although the recommended Olsen $\mathrm{P}$ levels of 12 (according to the MAF fertility model) were low by current standards. Stocking rates had lifted to record levels of 10 stock units per hectare, but per head production was very dependent on rainfall.

In the mid 1980s, a change in government economic policy and removal of the support mechanisms for agriculture saw profitability plummet as farmers struggled to survive. This period, combined with severe droughts in 1985 and 1988 saw some negative media publicity focus on farmer management of stock and land (e.g. dust storms). The concept of environmental sustainability started to gain prominence. Many agriculture advisers of the time were involved in the first serious attempt to encourage farmers to use direct drilling and other technologies to establish non-ryegrass based pastures through much of the east coast. At the risk of being accused of generalising, up until this point, ryegrass and 'Huia' white clover was the pasture mix of choice, from dairy farms in Northland to deer farms in Southland and everything in between!
The 1990s saw a return to higher farming returns (Table 2) and productivity (Table 3 ) through improved animal genetics and pasture cultivars. Wide ranges of pasture species and cultivar options became available, also improved market signals and variety of product options. Irrigation was also becoming very important in changing the face of pastoral agriculture, with a $100 \%$ increase in irrigated area from the mid 1980s (Figure 1) and a trend in land use away from pastoral agriculture (Figure 2).

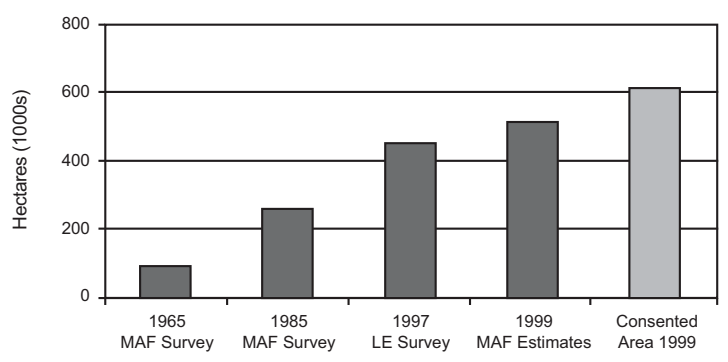

Figure 1 Irrigation areas in New Zealand.

(Source: Information on water allocation in New Zealand. Report No 4375/1, April 2002, MfE.)

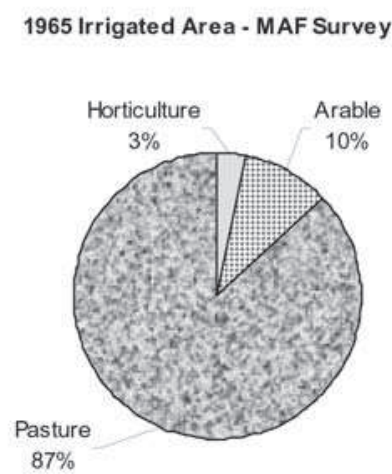

1997 Irrigated Area - LE Survey

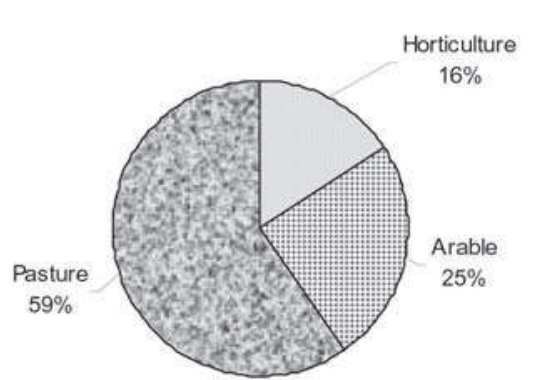

Figure 2 Trends in irrigation area by land use. (Source: Information on water allocation in New Zealand. Report No 4375/1, April 2002, Mfe.) 
Table 2 Summary of South Island finishing/breeding data from 1980-2003. Class 6 - MWI Economic Service

\begin{tabular}{|c|c|c|c|c|c|c|c|}
\hline Year & $\begin{array}{l}\text { Wool account } \\
\text { total }\end{array}$ & $\begin{array}{c}\text { Sheep account } \\
\text { total }\end{array}$ & $\begin{array}{c}\text { Cattle account } \\
\text { total }\end{array}$ & $\begin{array}{l}\text { Total gross } \\
\text { revenue }\end{array}$ & $\begin{array}{l}\text { Total farm } \\
\text { expenditure }\end{array}$ & $\begin{array}{l}\text { Farm profit } \\
\text { before tax }\end{array}$ & $\begin{array}{c}\text { Current value } \\
\text { as a going } \\
\text { concern at } \\
\text { close } \$ / \text { ha }\end{array}$ \\
\hline $1980-81$ & $\$ 33451$ & $\$ 31976$ & $\$ 9519$ & $\$ 81696$ & $\$ 63192$ & $\$ 18504$ & $\$ 1985$ \\
\hline 1981-82 & $\$ 41472$ & $\$ 36408$ & $\$ 9409$ & $\$ 93112$ & $\$ 77229$ & $\$ 15883$ & $\$ 2297$ \\
\hline 1982-83 & $\$ 38619$ & $\$ 38379$ & $\$ 8092$ & $\$ 95024$ & $\$ 81566$ & $\$ 13458$ & $\$ 2149$ \\
\hline 1983-84 & $\$ 39983$ & $\$ 40783$ & $\$ 6519$ & $\$ 99406$ & $\$ 83742$ & $\$ 15664$ & $\$ 2333$ \\
\hline 1984-85 & $\$ 48577$ & $\$ 51338$ & $\$ 9680$ & $\$ 124712$ & $\$ 96020$ & $\$ 28692$ & $\$ 1987$ \\
\hline $1985-86$ & $\$ 42440$ & $\$ 28053$ & $\$ 7122$ & $\$ 94839$ & $\$ 83541$ & $\$ 22298$ & $\$ 1480$ \\
\hline $1986-87$ & $\$ 51912$ & $\$ 38955$ & $\$ 10349$ & $\$ 115157$ & $\$ 86683$ & $\$ 28474$ & $\$ 1570$ \\
\hline 1987-88 & $\$ 58956$ & $\$ 39580$ & $\$ 11551$ & $\$ 121412$ & $\$ 97891$ & $\$ 23521$ & $\$ 1481$ \\
\hline 1988-89 & $\$ 55978$ & $\$ 24581$ & $\$ 8896$ & $\$ 99522$ & $\$ 91362$ & $\$ 8160$ & $\$ 1602$ \\
\hline $1989-90$ & $\$ 53970$ & $\$ 48328$ & $\$ 16060$ & $\$ 134243$ & $\$ 98681$ & $\$ 35562$ & $\$ 2011$ \\
\hline $1990-91$ & $\$ 38828$ & $\$ 50001$ & $\$ 17107$ & $\$ 120529$ & $\$ 99372$ & $\$ 21157$ & $\$ 2070$ \\
\hline 1991-92 & $\$ 42120$ & $\$ 50251$ & $\$ 18793$ & $\$ 127193$ & $\$ 100970$ & $\$ 26223$ & $\$ 2263$ \\
\hline $1992-93$ & $\$ 36122$ & $\$ 58914$ & $\$ 20926$ & $\$ 133605$ & $\$ 114886$ & $\$ 18719$ & $\$ 2768$ \\
\hline 1993-94 & $\$ 34863$ & $\$ 81779$ & $\$ 23723$ & $\$ 158426$ & $\$ 113833$ & $\$ 44593$ & $\$ 3412$ \\
\hline $1994-95$ & $\$ 52980$ & $\$ 72288$ & $\$ 22111$ & $\$ 164100$ & $\$ 123999$ & $\$ 40101$ & $\$ 3182$ \\
\hline $1995-96$ & $\$ 47675$ & $\$ 71471$ & $\$ 18973$ & $\$ 161729$ & $\$ 136883$ & $\$ 24846$ & $\$ 3080$ \\
\hline 1996-97 & $\$ 46411$ & $\$ 110000$ & $\$ 20005$ & $\$ 202035$ & $\$ 151057$ & $\$ 50978$ & $\$ 3240$ \\
\hline 1997-98 & $\$ 44685$ & $\$ 101259$ & $\$ 21317$ & $\$ 192144$ & $\$ 157036$ & $\$ 35108$ & $\$ 3135$ \\
\hline 1998-99 & $\$ 40673$ & $\$ 95618$ & $\$ 19163$ & $\$ 176445$ & $\$ 150688$ & $\$ 25757$ & $\$ 3168$ \\
\hline 1999-00 & $\$ 42160$ & $\$ 120783$ & $\$ 35518$ & $\$ 222801$ & $\$ 164318$ & $\$ 58483$ & $\$ 3548$ \\
\hline $2000-01$ & $\$ 52593$ & $\$ 165501$ & $\$ 45765$ & $\$ 292601$ & $\$ 199244$ & $\$ 93357$ & $\$ 4531$ \\
\hline 2001-02 & $\$ 49300$ & $\$ 184000$ & $\$ 51900$ & $\$ 312400$ & $\$ 189741$ & $\$ 122659$ & \\
\hline 2002-03 & $\$ 52200$ & $\$ 177000$ & $\$ 37300$ & $\$ 292300$ & $\$ 182520$ & $\$ 109780$ & \\
\hline
\end{tabular}

Table 3 Summary of South Island finishing/breeding data from 1980-2003 Class 6 - MWI Economic Service

\begin{tabular}{|c|c|c|c|c|c|c|c|c|c|}
\hline Year & $\underset{\%}{\operatorname{Lambing}}$ & $\begin{array}{c}\text { Total } \\
\text { effective } \\
\text { area (ha) }\end{array}$ & $\begin{array}{c}\text { WoolPro } \\
\text { per sheep } \\
\text { wt (kg) }\end{array}$ & $\begin{array}{c}\text { Stock units } \\
\text { per (S.U.) } \\
\text { ha }\end{array}$ & $\begin{array}{l}\text { Sheep S.U. } \\
\text { at open }\end{array}$ & $\begin{array}{l}\text { Cattle S.U } \\
\text { at open }\end{array}$ & $\begin{array}{l}\text { Deer S.U. } \\
\text { at open }\end{array}$ & $\begin{array}{l}\text { Goat S.U. } \\
\text { at open }\end{array}$ & $\begin{array}{c}\text { Total S.U. } \\
\text { at open }\end{array}$ \\
\hline $1980-81$ & 112.7 & 355 & 4.84 & 9.1 & 2801 & 432 & & & 3233 \\
\hline $1981-82$ & 104.3 & 356 & 4.42 & 9.2 & 2879 & 382 & & & 3261 \\
\hline 1982-83 & 100.1 & 353 & 4.13 & 9.0 & 2913 & 277 & & & 3190 \\
\hline $1983-84$ & 102.4 & 345 & 4.40 & 9.0 & 2826 & 265 & 4 & 5 & 3100 \\
\hline 1984-85 & 113.1 & 345 & 4.64 & 9.2 & 2869 & 277 & 9 & 8 & 3163 \\
\hline $1985-86$ & 103.8 & 353 & 4.55 & 8.8 & 2796 & 292 & 6 & 14 & 3108 \\
\hline $1986-87$ & 105.2 & 352 & 4.59 & 9.2 & 2878 & 335 & 5 & 17 & 3235 \\
\hline 1987-88 & 111.0 & 360 & 4.79 & 8.9 & 2830 & 370 & 8 & 13 & 3221 \\
\hline 1988-89 & 101.7 & 358 & 4.05 & 9.0 & 2829 & 373 & 10 & 19 & 3231 \\
\hline $1989-90$ & 101.4 & 364 & 4.52 & 8.2 & 2601 & 326 & 19 & 22 & 2968 \\
\hline $1990-91$ & 103.2 & 381 & 4.24 & 8.3 & 2748 & 376 & 35 & 17 & 3176 \\
\hline 1991-92 & 105.4 & 386 & 4.48 & 8.3 & 2772 & 398 & 28 & 9 & 3207 \\
\hline $1992-93$ & 92.1 & 378 & 4.11 & 8.4 & 2677 & 437 & 50 & 10 & 3174 \\
\hline 1993-94 & 108.0 & 366 & 4.70 & 8.3 & 2544 & 449 & 37 & 8 & 3038 \\
\hline 1994-95 & 114.3 & 410 & 4.75 & 8.8 & 2965 & 569 & 39 & 17 & 3590 \\
\hline $1995-96$ & 102.4 & 425 & 4.39 & 8.8 & 3073 & 632 & 49 & 5 & 3759 \\
\hline $1996-97$ & 115.5 & 436 & 4.72 & 8.8 & 3133 & 629 & 53 & 7 & 3822 \\
\hline $1997-98$ & 118.8 & 439 & 4.59 & 9.0 & 3186 & 680 & 59 & 7 & 3932 \\
\hline $1998-99$ & 118.9 & 430 & 4.82 & 8.5 & 3022 & 565 & 51 & 6 & 3644 \\
\hline 1999-00 & 118.3 & 448 & 4.67 & 8.6 & 3120 & 653 & 67 & 5 & 3845 \\
\hline 2000-01 & 118.0 & 472 & 4.96 & 8.6 & 3238 & 724 & 102 & 4 & 4068 \\
\hline $2001-02 p$ & - & 472 & 4.77 & 8.2 & 3076 & 727 & 71 & 4 & 3878 \\
\hline $2002-03 e$ & - & 472 & 4.74 & 8.4 & 3111 & 786 & 72 & 4 & 3973 \\
\hline
\end{tabular}


Consequently, farming systems are considerably more varied, because farmers have adopted systems that give the desired risk and reward trade-off for the land, water, and capital resources. However, white clover is still the legume of predominant use, primarily because it is relatively inexpensive, widely available, and well known. By comparison, alternative legume adoption has been limited by lack of industry and research support, the high cost of seed, lack of seed supply, and limited range of cultivar choices. The authors have estimated the approximate volumes of seed sold in NZ each year at 1 000-1 200 tonnes for white clover, compared with only 100-150 tonnes of red clover, 150-200 tonnes of lucerne, 40-60 tonnes of subterranean clover, and 30-50 tonnes for all other forage legumes combined.

The important point to take from this brief historical summary is that for 50 years post-World War II, base farming systems remained relatively unchanged. Over the past 10 years, there has been a revolution in both the technologies available and the farming systems employed. Thus, a challenge for farmers, policy makers, agribusiness owners and scientists, is to not apply yesterday's thinking to the role of legumes in future farming systems.

\section{The roles legumes play in dryland farming systems}

There are five distinct and definable roles for legumes to fill.

1. Perennial workhorse: Legumes which persist within a general-purpose perennial pasture and produce high quality feed when soil fertility and moisture allow. This has traditionally been the role of white and sub clovers.

2. Nitrogen producers: Legumes which serve as a nitrogen source, either within a short-term pasture or crop or within a perennial pasture. There is obvious economic impact is ( $\$ 210 \mathrm{M}$ per year for the South Island dryland alone, Table 4), but with increasing regulatory and market demand for environmental sustainability, nitrogen production is also "eco-friendly". Nitrogen's importance to grass dry matter production and grass quality under a dryland environment is well known and documented.
3. High quality summer feed source: Legumes can improve summer feed quality within a grass mix when the quality of grasses has deteriorated. The superiority of legumes over grass for animal production in summer is well known (Table 5), resulting in greater productivity and feed conversion efficiency (Table 6).

4. Contributors to year round feed quality: Legumes can be used as a specialist crop to be grazed in situ or conserved as hay or silage. Both perennial crops (e.g. lucerne) and shorter term crops (e.g. 'Sulla') have roles within dryland systems to maximise meat production and dry matter production per hectare.

5. Designer Feeds: Legumes can serve as a component of "designer" or specialist composite feeds. Condensed tannins, that facilitate more efficient protein conversion, chemical compounds that achieve lower internal parasite burdens, and those that achieve a change in meat flavour are already conceivable, if not yet achievable.

Table 4 Estimated annual value of nitrogen fixed by cloverbased pastures in dryland regions of the South Island $(800 \mathrm{~mm}$ or less of annual rainfall).

\begin{tabular}{lcccc}
\hline $\begin{array}{l}\text { Land } \\
\text { class }\end{array}$ & $\begin{array}{c}\text { Area in pastoral } \\
\text { production } \\
(\mathrm{M} \mathrm{ha})\end{array}$ & $\begin{array}{c}\text { Estimated N } \\
(\mathrm{kg} \mathrm{N} / \mathrm{ha} / \mathrm{yr})\end{array}$ & $\begin{array}{c}\mathrm{N} \text { fixation } \\
(\text { Tonnes/yr) }\end{array}$ & $\begin{array}{c}\text { Value }^{\mathrm{c}} \\
(\text { million\$) }\end{array}$ \\
\hline$<15^{\circ}$ slope & 1.406 & 185 & 26010 & 338 \\
$>15^{\circ}$ slope & 0.775 & 20 & 15000 & 19 \\
\hline Total & 2.181 & 126 & 275610 & 357 \\
\hline
\end{tabular}

aSource: NIWA

'Source: Hoglund et al. (1979)

'Source: Applied Nitrogen costs estimated at \$1 300/tonne.

Table 5 Percentage protein, carbohydrate and comparative sheep live weight gain of ryegrass, white clover and lucerne.

\begin{tabular}{lcccc}
\hline & $\begin{array}{c}\text { Crude } \\
\text { protein } \\
(\%)\end{array}$ & $\begin{array}{c}\text { Useable } \\
\text { carbohydrate } \\
(\%)\end{array}$ & $\begin{array}{c}\text { Structural } \\
\text { carbohydrate } \\
(\%)\end{array}$ & $\begin{array}{c}\text { Comparative } \\
\text { live weight } \\
\text { gain (g/hd/d) }\end{array}$ \\
\hline $\begin{array}{l}\text { Perennial } \\
\text { ryegrass }\end{array}$ & 16 & 12 & 30 & 100 \\
White clover & 25 & 20 & 17 & 192 \\
Lucerne & $18-20$ & 15 & 25 & 157 \\
\hline
\end{tabular}

Source: Ulyatt (1981) 
Table 6 Total energy consumed rearing a lamb from 25 to $35 \mathrm{~kg}$ of live weight at various daily growth rates. (MJME: megajoules of metabolisable energy)

\begin{tabular}{lccc}
\hline & $\begin{array}{c}\text { Energy/lamb/day } \\
\text { (MJME) }\end{array}$ & Days on farm & $\begin{array}{c}\text { Energy consumed } \\
\text { per lamb (MJME) }\end{array}$ \\
\hline 100 grams/day & 13 & 100 & 1300 \\
200 grams/day & 17 & 50 & 850 \\
300 grams/day & 22 & 33 & 726 \\
\hline
\end{tabular}

Source: Brown (1990)

\section{Factors in legumes favour}

- Better understanding by farmers of their farming systems through monitoring. Growers are no longer looking for all their requirements to be delivered by a single cultivar. They understand and are adopting the technically advanced management systems often required by modern cultivars.

- Better soil fertility. P levels in excess of 20 are now commonplace.

- Better technology. Examples include drills, subdivision, computer decision aids, precision agriculture tools, novel grass endophytes that are more clover friendly and double spray techniques for moisture conservation.

- Better pasture management. Farmers are prepared to feed supplements or sell stock early to spell pastures to allow recovery when moisture arrives.

- Flexible systems. The variety of stock systems within a farm and the choices of companion grasses provide greater opportunity for a legume to receive the management it requires to perform well.

\section{Challenges for legumes}

- Competition from grasses. New ryegrass cultivars released to the market yielded $6 \%$ more herbage annually on average and $9 \%$ in summer, than cultivars available before 1991. (Easton et al. 2001)

- Competition from pests. While perennial pests such as slugs, nematodes and grass grub still cause significant damage, more recent arrivals such as clover root weevil will continue to be a problem.

- Competition from nitrogen fertiliser. With an increasing need to achieve maximum growth during buoyant periods of adequate moisture, applied nitrogen will become an increasingly common practice.

- Time pressures. The need to optimise valuable land resources means a legume with a slow establishment phase is not very useful.

- Moisture availability. As water becomes a more scarce and expensive resource, it will only be directed where there is adequate productivity and financial payback. This may not be a legume, but a forge cereal, or other crops, resulting in the semi-irrigated legume becoming a true dryland site, or in legumes not being planted at all, due to their inability to perform in low or limited moisture situations.

- Persistence in drought. New cultivars must achieve better persistence and the capacity to survive periods of adversity, particularly the combination of drought and overgrazing.

- Lower temperature thresholds. In dryland environments, periods of adequate moisture frequently coincide with autumn, winter, and spring, when soil and air temperatures are hovering in the 5 to $8^{\circ} \mathrm{C}$ range.

\section{Conclusion}

Legumes play a well documented, vital role in New Zealand pastoral agriculture, for the nitrogen they contribute, and the quantity and quality contribution they make to the grazing sward, and hence animal productivity.

There has been a major evolutionary change to dryland systems since the mid 1990s, with a renewed confidence in the productivity and opportunities in this class of land. Wide ranges of farming systems have developed to both improve profitability and reduce the exposure to dry summers. The complex nature of dryland farming systems has produced a wide variability in farmer's seasonal dry matter production and feed quality needs. There is an opportunity and a need to widen the range of legumes used, and moving away from the dominance of white clover and acquiring the knowledge and management skill that each of these specialist legumes require. If this can be achieved, there will be a further improvement in productivity, sustainability and profitability of dryland farming systems, and hence, New Zealand agriculture. 


\section{ACKNOWLEDGMENTS}

The authors would like to thank Grant McFadden of MAF Policy for his assistance in providing data and advice regarding the issues related to dryland farmers.

\section{REFERENCES}

Brown, C. 1990. An integrated herbage system for Southland and Otago. Proceedings of the New Zealand Grassland Association 52: 119-122.

Brown, C. 1996. Financial viability - a long term view. Proceedings of the New Zealand Grassland Association 58: 712.

Easton, H.S.; D.B.; Cameron, N.E.; Kerr, G.A.; Norris, M.; Stewart, A.V. 2001. Perennial ryegrass cultivars: herbage yield in multi-sire plots. Proceedings of New Zealand Grassland Association. 63: 183-188.

Hoglund, J.H.; Crush, J.R.; Brock, J.L.; Ball, R.; Carran, R.A. 1979. Nitrogen fixation in pasture XII. General discussion. New Zealand Journal of Experimental Agriculture 7: 45-51.

Lincoln Environmental: Information on Water Allocation in New Zealand. Report No 4375/1 April 2000.

MWI Economic Services, Class 6 South Island finishing/breeding data 1980-2003

Ulyatt, M.J. 1981. The feeding value of herbage: Can it be improved? New Zealand Agricultural Science 15: 200-205. 